\title{
Improving Visual Literacy Skills of Elementary School Students Against Science Materials in Online Learning
}

\author{
Rudhya Nurul Ilma1, M. Muktiarni2,*, Jonah Mupita ${ }^{3}$ \\ ${ }^{1}$ Departemen Pendidikan Biologi, Universitas Pendidikan Indonesia, Indonesia \\ ${ }^{2}$ Departemen Pendidikan Kesejahteraan Keluarga, Universitas Pendidikan Indonesia, \\ Indonesia \\ ${ }^{3}$ Ruya Adventist High School, Zimbabwe \\ *Corresponding author: muktiarni@upi.edu
}

\begin{abstract}
Abstrak: Kemampuan literasi merupakan hal mendasar yang harus dimiliki siswa dalam menghadapi era global untuk dapat memenuhi kebutuhan hidup dalam berbagai situasi. Tujuan dari penelitian ini adalah untuk menguji penguasaan literasi sains siswa kelas 5 SD yang diukur dengan soal-soal bergambar yang difokuskan pada mata pelajaran biologi. Penelitian ini dilakukan pada siswa kelas V SD Negeri 10 Cibiru Bandung. Sampel terdiri dari 10 siswa yang diambil dengan metode cluster random sampling. Tahapan penelitian ini adalah pre-test - treatment - post-test. Kesimpulannya masih banyak siswa yang belum mengetahui literasi sains. Hasil penelitian menunjukkan bahwa rata-rata skor post-test siswa sebesar 80,1\%, lebih besar dari rata-rata skor pre-test yaitu 40,8\%, sehingga selisihnya adalah 39,3\%. Oleh karena itu, kompetensi inti dapat meningkatkan minat siswa terhadap literasi sains. Pemahaman siswa terhadap materi "organ pernapasan" dapat ditingkatkan dengan meningkatkan kompetensi inti dengan penyampaian materi menggunakan Powerpoint atau platform YouTube yang dilakukan secara daring melalui aplikasi Zoom dengan pendidik.
\end{abstract}

Kata kunci: literasi visual, literasi sains, organ pernapasan, sekolah dasar

\begin{abstract}
Literacy ability is a fundamental thing that must be possessed by students in facing the global era to be able to meet the needs of life in various situations. The purpose of this study was to examine the mastery of science literacy for grade 5 elementary school students as measured by pictorial questions focused on biology subject. This activity was conducted on fifth grade students at Cibiru 10 Elementary School Bandung. The sample consisted of 10 students who were taken by cluster random sampling method. This activity stage is pre-test treatment - post-test. The conclusion is that there are still many students who do not know scientific literacy. The results showed that the average post-test score of students was $80.1 \%$ greater than the average pre-test score of $40.8 \%$, so the difference was $39.3 \%$. Therefore, Core Competencies can increase students' interest in scientific literacy. students' understanding of the material "respiratory organs" can be improved by increasing core competencies by delivering material via Powerpoint or YouTube platform which is carried out online from the use of the Zoom application with educators.
\end{abstract}

Keywords: visual literacy, scientific literacy, respiratory organs, elementary school

\section{Introduction}

In elementary schools, science learning is a very important subject because it makes students think critically, act realistically, be able to solve problems that occur in the 
environment around us and be able to compete internationally (Kayan, 2021). Science learning aims to develop science process skills, as well as solve problems and draw conclusions based on understanding scientific concepts obtained from observations of the natural environment (Arifin, 2020). The science learning process should provide a direct learning experience based on the development of process skills and scientific attitudes. With direct learning, students can solve various types of simple problems related to real life, this will motivate students actively in compiling their knowledge to obtain the expected science learning outcomes (Akbari et al., 2021).

Learning that aims to improve students' abilities optimally must be done through structured and measurable steps. One way to arrange learning in accordance with these principles is to use a scientific approach (Setiawan, 2019). The scientific approach has high effectiveness in improving the learning outcomes of each cognitive aspect of students at the level of knowledge, understanding, and application. In general, the scientific approach is structured over several steps of activity in sequence; observing, asking, collecting information, conducting experiments, processing data, and communicating the results (Setiawan, 2019). This step is used to provide experience to students so that the information obtained is more meaningful, tested, and can be accounted for (Setiawan, 2019).

Scientific literacy is the ability to use scientific knowledge in an effort to solve problems. literacy is important to be mastered by students in the way students get to the environment, health, economy, and other problems faced by modern society who really understand technology and progress, as well as the development of science (Asyhari and Hartati, 2016). Scientific literacy is an ability that does not only read or write but the ability to understand science, distribute scientific information orally and in writing, apply scientific skills to solve problems, and have a high sensitivity to oneself and the surrounding environment (Putri et al., 2021).

One of the lessons that became an interesting discussion material for educators along with the implementation of the 2013 curriculum was scientific learning. Learning that adheres to constructivism is considered to be able to answer the demands of national education goals to be achieved at this time. The application of this learning becomes a challenge for the teacher through the development of student activities during the learning activities (Asyhari and Hartati, 2016). Activities in scientific learning are activities designed to be able to develop thinking skills so that they can develop students' curiosity (Asyhari and Hartati, 2016).

At the elementary school level, Natural Sciences or science is one of the subjects that 
occupies an important role in education, this is because science can be a provision for students in facing various challenges in the global era (Yuliati, 2017). Therefore, a learning method is needed that can prepare students to have good competencies and be literate in science and technology, able to think logically, critically, creatively, argue correctly, be able to communicate and collaborate. Science literacy can be termed as scientific literacy ability, namely the ability to understand science, communicate science (oral and written), and apply scientific abilities to solve problems so that they have a high attitude and sensitivity to themselves and their environment in making decisions based on scientific considerations. (Yuliati, 2017).

Based on PISA (Program for International Student Assessment) data, the scientific literacy ability of Indonesian students is still below the average when compared to the international average score and is generally at the lowest stage of PISA measurement (Yuliati, 2017; Setiawan, 2020). One of the factors thought to contribute to the student's difficulties is the inability of a teacher to visualize phenomena related to the material being studied (Damayana et al., 2018). Some experts in their research suggest that one way to overcome these student difficulties is to provide a learning media that is able to visualize a phenomenon, making it easier for students to criticize concepts (Damayana et al., 2018). Visualization given during learning is considered important because it can facilitate students in thinking critically about the material being studied. Visualization can be presented in various visual forms that will provide a lot of information that reinforces and complements verbal content (Damayana et al., 2018).

The problem that is often faced by prospective teachers in the application of deep scientific literacy is that they have rarely been led to think at a high level in learning, then coupled with weaknesses in communicating ideas or information in a straightforward manner, lack of insight in reading literature and lack of insight into thinking (Syofyan, 2019). This engagement on the application of scientific literacy in science learning materials for prospective elementary school teachers in facing 21 st century education is to facilitate prospective elementary school teachers to apply things that support science literacy learning, namely teachers teach students to be able to construct meaning, determine to use learning models active as a learning model, and teachers must be capable in their fields, must master technology, be able to carry out learning to improve student competence, certainty of choice to teach and teachers must be able to teach in multicultural conditions (Syofyan, 2019).

Breathing is the activity of air and exhalation. Air contains various gas components, one 
of which is oxygen (O2). This oxygen is needed by the body. Oxygen enters the body through breathing. Furthermore, breathing produces carbon dioxide (CO2) which is removed from the body. Breathe using breathing apparatus. The human respiratory organs are the nose, throat and lungs (Chandra et al., 2021).

The theme of human respiratory organs and the health of human respiratory organs is a thematic material for class V SD, is a sub-theme 2 focused on learning Indonesian, PPKn, IPA, IPS, SBdP with the scope of learning 1 to learning 3. In learning, the theme of human respiratory organs includes: (1) the names of the human respiratory organs. (2) the function of the human respiratory organs. (3) diseases of the respiratory organs. (4) how to maintain the health of the respiratory organs. Based on the description above, this study aims to describe increasing the profile of students' scientific literacy skills through scientific learning.

\section{Methods}

This activity approach is a qualitative approach with the method used is the case study method. Data collection techniques in the form of pre-test, treatment, post-test and observation. The pre-test will contain 12 multiple choices via the Quizizz app. This was done to determine the students' initial knowledge about the respiratory organ material and to compare it with the post-test results. After being given a pre-test, we will provide learning for 5 meetings, namely by giving learning videos and powerpoints to students as shown in Fig. 1. Then students will be asked to read for 15 minutes and watch the learning video before learning and ask students to send photos or videos as evidence that they are reading. After that, students will be asked about the material they read before through a question and answer session in a zoom meeting. After the activity is complete, students will be given a post-test through the Quizizz application with the same choice of questions and answers as in the pre-test as shown in Fig. 2. This is done to find out what changes occur in children after doing this movement. The data that has been collected is then analyzed and processed to obtain results and conclusions. 
Jurnal Abdimas Kartika Wijayakusuma ISSN 2716-3512 (Online) ISSN 2721-0367 (Print)
This work is licensed under a Creative Commons Attribution-ShareAlike 4.0 International License.
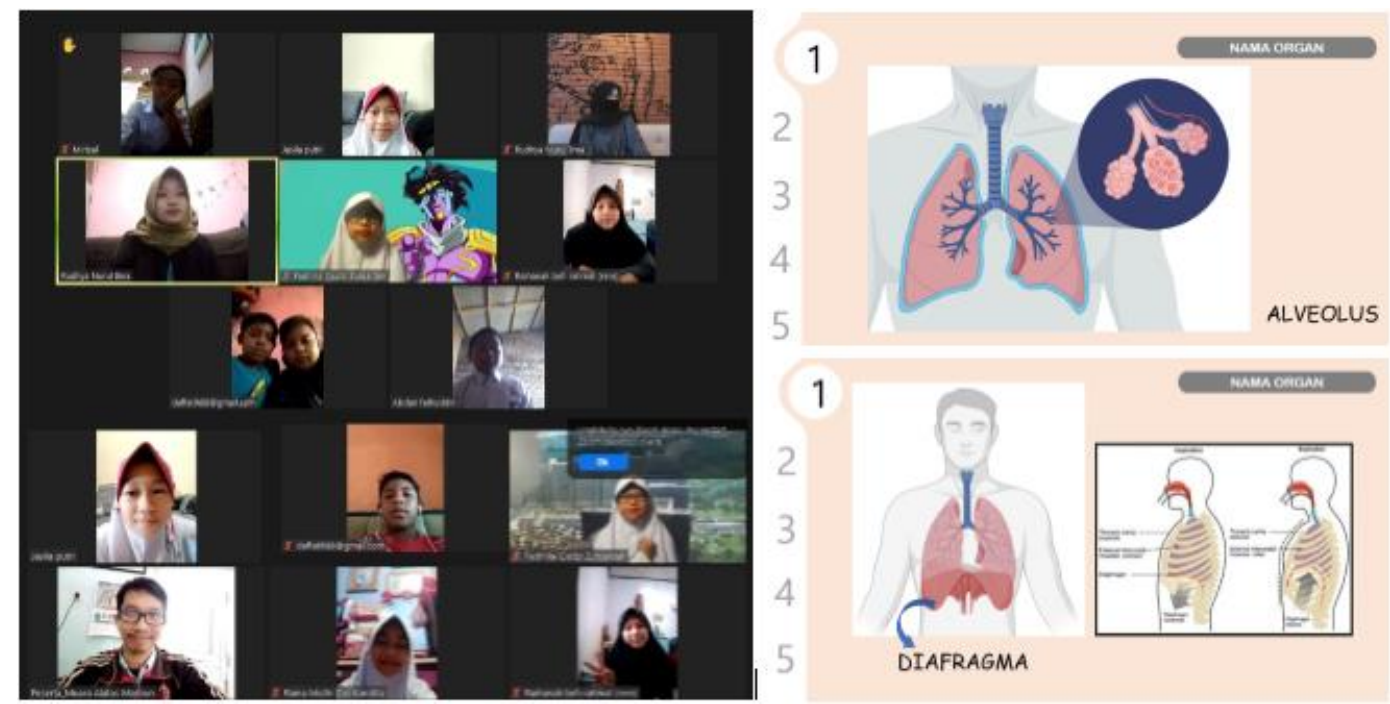

Fig. 1. Online learning activities through the zoom application
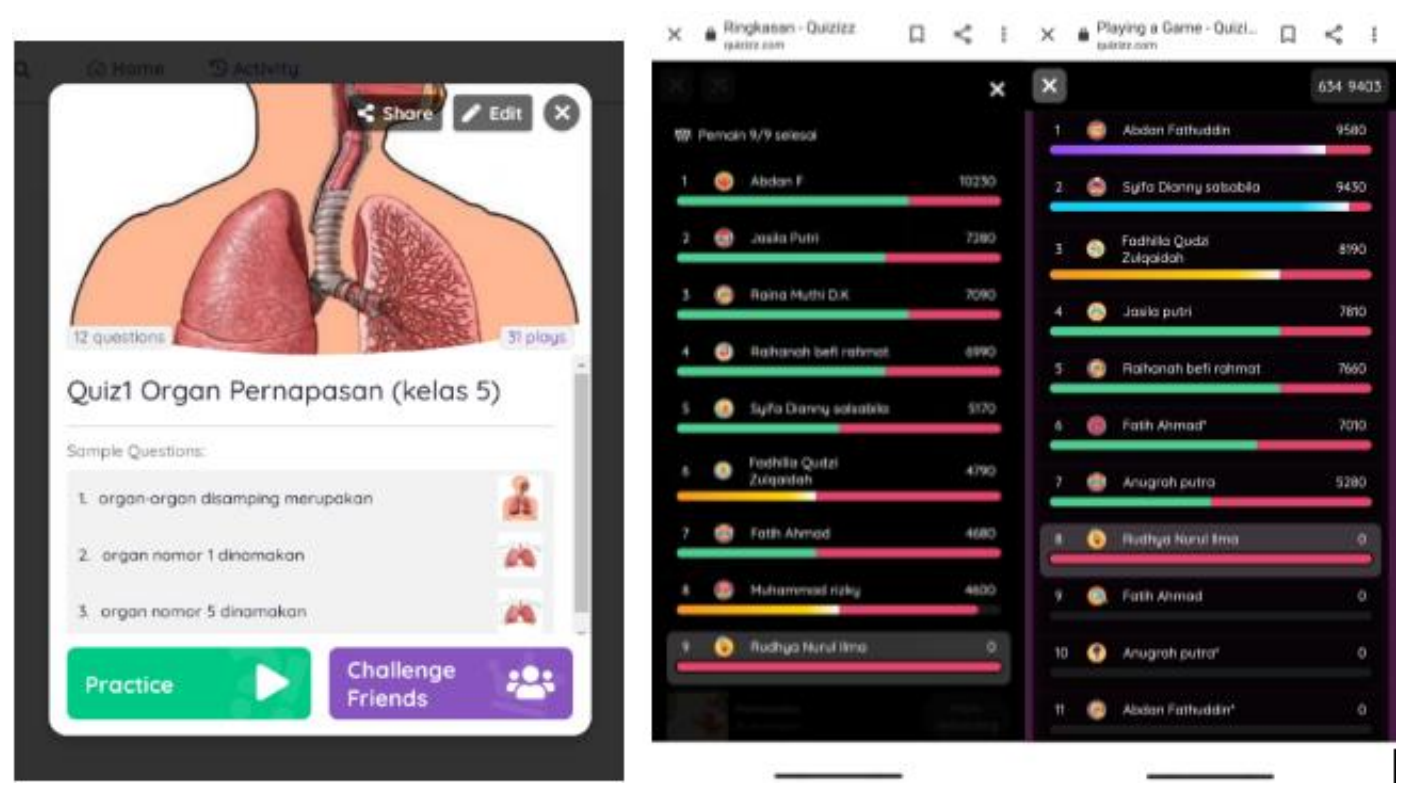

Fig. 2. Pre-test and post-test via Quizizz app

\section{Result and Discussion}

\subsection{Demography}

This activity was conducted in elementary schools. The first step in this activity is to survey the number of students in the school by interviewing the principal. The number of students recorded was 365 . Then we chose a sample from the population and obtained 10 students with details of 6 students male and 4 female students from class V. 
Jurnal Abdimas Kartika Wijayakusuma ISSN 2716-3512 (Online) ISSN 2721-0367 (Print)
This work is licensed under a Creative Commons

Attribution-ShareAlike 4.0 International License.

\subsection{Pre-Test and Post-Test Result}

Table 1 describes the difference in the scores of the questions posed by the pre-test and post-test. The first questionnaire that was made was a pre-test questionnaire. This questionnaire was distributed to fifth grade elementary school students, which aims to find out the extent of the material on "human respiratory organs" by filling out 12 questions. After that, we will provide material about "human respiratory organs" through YouTube video and Powerpoint learning media. After explaining the material, we redistributed the questionnaire with the same questions in the form of a posttest to students with the aim of understanding the material "human respiratory organs".

Table 1. Pre-test and post-test results.

\begin{tabular}{|c|c|c|c|c|c|c|}
\hline \multirow{2}{*}{ No. } & \multirow{2}{*}{ Questions topic } & \multirow{2}{*}{$\begin{array}{c}\text { No. } \\
\text { question }\end{array}$} & \multicolumn{2}{|c|}{ Pre-test } & \multicolumn{2}{|c|}{ Post-test } \\
\hline & & & true & false & true & false \\
\hline 1 & $\begin{array}{l}\text { image provided. Students are asked what is } \\
\text { the name of the organ designated }\end{array}$ & $1-4,12$ & $32.0 \%$ & $60.8 \%$ & $64.0 \%$ & $36.0 \%$ \\
\hline 2 & $\begin{array}{l}\text { image provided. Students are asked the } \\
\text { function of the designated organ }\end{array}$ & 5 & $30.0 \%$ & $70.0 \%$ & $100.0 \%$ & $0.0 \%$ \\
\hline 3 & $\begin{array}{l}\text { provide an overview of an organ. Students } \\
\text { are asked the name of the organ in question }\end{array}$ & 6 & $30.0 \%$ & $70.0 \%$ & $80.0 \%$ & $20.0 \%$ \\
\hline 4 & respiratory system disorders & 7 & $40.0 \%$ & $60.0 \%$ & $70.0 \%$ & $30.0 \%$ \\
\hline 5 & cause of respiratory problems & $8,9,11$ & $43.0 \%$ & $57.0 \%$ & $76.7 \%$ & $23.3 \%$ \\
\hline 6 & $\begin{array}{l}\text { how to maintain the health of the respiratory } \\
\text { organs }\end{array}$ & 10 & $70.0 \%$ & $30.0 \%$ & $90.0 \%$ & $10.0 \%$ \\
\hline & & 12 & $40.8 \%$ & & $80.1 \%$ & \\
\hline
\end{tabular}

The results show several discussion points:

(i) Question topic number one increased by $32.0 \%$ after giving the material

(ii) Question topic number two improved the most among other questions by $70.0 \%$ after being given the material

(iii) Question topic number three results increased by $50.0 \%$ before and after giving the material.

(iv) The result of question topic number four increased by $30.0 \%$ after being given the material.

(v) Question topic number five results increased $33.7 \%$ after being given the material

(vi) Question topic number six results increased by $20 \%$ after being given the material 


\section{Conclusion}

The conclusion is that there are still many students who do not know scientific literacy. The results showed that the average post-test score of students was $80.1 \%$ greater than the average pre-test score of $40.8 \%$, so the difference was $39.3 \%$. Therefore, Core Competencies can increase students' interest in scientific literacy. students' understanding of the material "respiratory organs" can be improved by increasing core competencies by delivering material via powerpoint or YouTube which is carried out online from the use of the zoom application with educators. Online learning through the zoom application and giving assignments on Quizizz app can be one of the easiest ways to implement this distance learning program.

\section{Acknowledgement}

We acknowledged Bangdos, Universitas Pendidikan Indonesia. We thank to Muara Alantas, S.Pd. from Cibiru 10 Elementary school Bandung. This study is a part of community service (Program: KKN Tematik Literasi 2021 (August-Sept 2021) kel. 22) Lembaga Penelitian dan Pengabdian Masyarakat (LPPM), Universitas Pendidikan Indonesia. We also thank to Kantor Jurnal dan Publikasi, Directorate of International Affairs, Universitas Pendidikan Indonesia. We thank to Nissa Nur Azizah, Dwi Fitria Al Hussaeni, Dr.Eng. Asep Bayu Dani Nandiyanto, S.T., M.Eng., M.Pd., Rina Maryanti, S.Pd., M.Pd., and Asri Wibawa Sakti, M.Pd.

\section{References}

Akbari, U. F., Aiman, U., Ahmad, R. A. R. 2021. Model word squareber bantuan media gambar dalam pelajaran IPA konsep organ pernapasan manusia terhadap hasil belajar pada siswa kelas V SD. Jurnal Elementary: Kajian Teori dan Hasil Penelitian Pendidikan Sekolah Dasar, 4(2), 108-111.

Arifin, D. 2020. Penerapan model pembelajaran quantum learning untuk meningkatkan hasil belajar IPA peserta didik kelas V sekolah dasar. Jurnal Pendidikan Dasar Flobamorata, 1(1), 22-30.

Asyhari, A., Hartati, R. 2016. Profil peningkatan kemampuan literasi sains siswa melalui Pembelajaran Saintifik. Jurnal Ilmiah Pendidikan Fisika Al-BiRuNi, 4(2), 179-191.

Chandra, A., Firman, F., Desyandri. 2021. Peningkatan hasil belajar siswa pada materi organ pernapasan manusia menggunakan model Problem Based Learning (PBL) di Kelas V SD Negeri 08 Puncak Lawang. Jurnal Pendidikan Tambusai, 5(1), 120-126.

Damayana, H., Setyarini, M., Rosilawati, I. 2018. Pengembangan lembar kerja siswa berbasis literasi visual pada materi asam basa. Jurnal Pendidikan dan Pembelajaran Kimia, 1, 112. 
Kayan, G. A. 2021. Penerapan model pembelajaran kooperatif tipe make a match berbantuan multimedia untuk meningkatkan hasil belajar PPKN siswa kelas V C SD Widiatmika tahun pelajaran 2020/2021. Jurnal Pendidikan Dasar Flobamorata, 2(1), 118-125.

Putri, D. P., Setiyani, Anggraeni, R. 2021. Development of teaching materials based of science literacy module of animal and human respiratory organs. Pedagogi: Jurnal Penelitian Pendidikan, 8(1), 57-68.

Setiawan, A. R. 2019. Peningkatan literasi saintifik melalui pembelajaran biologi menggunakan pendekatan saintifik. JOBE (Jurnal of Biology Education), 2(1), 1-13.

Setiawan, A. R., Saputri, W. E. 2020. Pembelajaran literasi saintifik untuk pendidikan dasar. Media Penelitian Pendidikan: Jurnal Penelitian dalam Bidang Pendidikan dan Pengajaran, 14(2), 144-152.

Syofyan, H. 2019. Penerapan literasi sains dalam pembelajaran IPA untuk calon guru SD. JPD: Jurnal Pendidikan Dasar, 10(2), 35-43.

Yuliati, Y. 2017. Literasi sains dalam pembelajaran IPA. Jurnal Cakrawala Pendas, 3(2), 2128. 